Article

\title{
Purification and Characterization of Iso-Ribonucleases from a Novel Thermophilic Fungus
}

\author{
Kyle S. Landry and Robert E. Levin * \\ Department of Food Science, Massachusetts Agricultural Experiment Station, \\ University of Massachusetts, Amherst, MA 01003, USA; E-Mail: kslandry@foodsci.umass.edu \\ * Author to whom correspondence should be addressed; E-Mail: relevin@foodsci.umass.edu; \\ Tel.: +1-413-545-0187; Fax: +1-413-545-1262.
}

Received: 10 December 2013; in revised form: 31 December 2013 / Accepted: 2 January 2014 / Published: 10 January 2014

\begin{abstract}
A thermophilic fungus previously isolated from composted horse manure was found to produce extracellular iso-RNases that were purified 127.6-fold using a combination of size exclusion chromatography and a novel affinity membrane purification system. The extent of purification was determined electrophoretically using $4 \%-15 \%$ gradient polyacrylamide gels. RNase activity was dependent on the presence of a metal co-factor with significantly more activity with $\mathrm{Zn}^{2+}$ or $\mathrm{Mn}^{2+}$ than $\mathrm{Mg}^{2+}$. The RNases exhibited maximum activity at both $\mathrm{pH} 3.0$ and $\mathrm{pH} 7.0$ with no activity at $\mathrm{pH} 2.0$ or 10.0 . The optimal temperature for the iso-RNase was $70{ }^{\circ} \mathrm{C}$. The molecular weight of the iso-RNase was determined to be $69 \mathrm{kDa}$ using a Sephadex G-75 column.
\end{abstract}

Keywords: affinity purification; RNase purification; chromatography; thermophilic fungi; RNase characterization

\section{Introduction}

Ribonucleases (RNase) are found in all organisms including animals, plants and microorganisms and were the first nucleases to be described [1]. Ribonuclease A was first purified and crystallized from beef pancreas by Kunitz [2]. Ribonucleases can hydrolyze single stranded or double stranded RNA as well as RNA present as a DNA-RNA hybrid [3]. Bovine pancreatic ribonuclease is the most characterized of all nucleases and was the first enzyme to be subjected to sequencing, protein 
crystallographic, and protein folding studies [4]. Currently there are hundreds of known RNases that have been fully or partially characterized, with many more to be discovered.

Recently a thermophilic fungus was isolated and found to produce an extracellular DNase [5]. It was later found that the isolate also produces an extracellular RNase. This manuscript describes the purification and characterization of the extracellular RNase produced by the isolate.

\section{Results and Discussion}

\subsection{Concentration of Crude RNase}

Following filtration and dialysis of the culture, the enzyme activity of the crude sample was analyzed for RNase activity using the acid soluble assay at $55^{\circ} \mathrm{C}$. The crude sample $(250 \mathrm{~mL})$ was then concentrated at room temperature to $39 \mathrm{~mL}$ using an ultra-filtration apparatus with a membrane cut off of $10 \mathrm{kDa}$, resulting in a concentration factor of 6.41 .

Enzyme activities from both the crude and concentrated enzyme preparations were plotted and their slopes analyzed (Figure 1). If no enzyme activity was lost during the concentration then the rate or slope of the concentrated sample when divided by the concentration factor should equal that of the crude preparation.

The rate of activity of the concentrated enzyme, when divided by the concentration factor was $98 \%$ of the original crude activity slope, indicating that only $2 \%$ of the total enzyme activity was lost during the concentration process (Table 1). Overall there was a 9.07-fold increase in specific activity when compared to the original crude sample based on the Lowry assay. In regards to overall protein, the crude sample had $320 \mathrm{mg}$ of protein and after membrane concentration; the overall protein content was reduced by $89 \%$ to $35 \mathrm{mg}$ according to the Lowry assay (Table 1 ).

Table 1. Overall purification of the thermophilic RNase ${ }^{\mathrm{a}}$.

\begin{tabular}{ccccccc}
\hline Fraction & $\begin{array}{c}\text { Vol } \\
(\mathbf{m L})\end{array}$ & $\begin{array}{c}\text { Protein } \\
\text { Content }(\mathbf{m g})\end{array}$ & $\begin{array}{c}\text { Total } \\
\text { activity }(\mathbf{U})\end{array}$ & $\begin{array}{c}\text { Sp act } \\
(\mathbf{U} / \mathbf{m g})\end{array}$ & $\begin{array}{c}\text { Recovery } \\
\mathbf{( \% )}\end{array}$ & $\begin{array}{c}\text { Increase in } \\
\text { sp act }\end{array}$ \\
\hline Crude & 250.0 & 320.0 & 10,476 & 33 & 100 & 1 \\
Concentrated & 39.0 & 35.0 & 10,257 & 293 & 98 & 8.9 \\
Sephadex G-50 & 46.2 & 2.8 & 8456 & 3020 & 81 & 91.5 \\
Membrane & 45 & 1.9 & 8006 & 4214 & 76 & 127.6 \\
\hline
\end{tabular}

${ }^{a}$ One unit of enzyme activity is defined as an increase in absorbance of 0.1 units in a cuvette of $1 \mathrm{~cm}$ path length at $260 \mathrm{~nm}$. 
Figure 1. Comparison of the rates or slopes of the crude and concentrated samples in regards to enzyme activity. The assay used for these experiments was the acid soluble assay which was performed in triplicate at $55^{\circ} \mathrm{C}$.

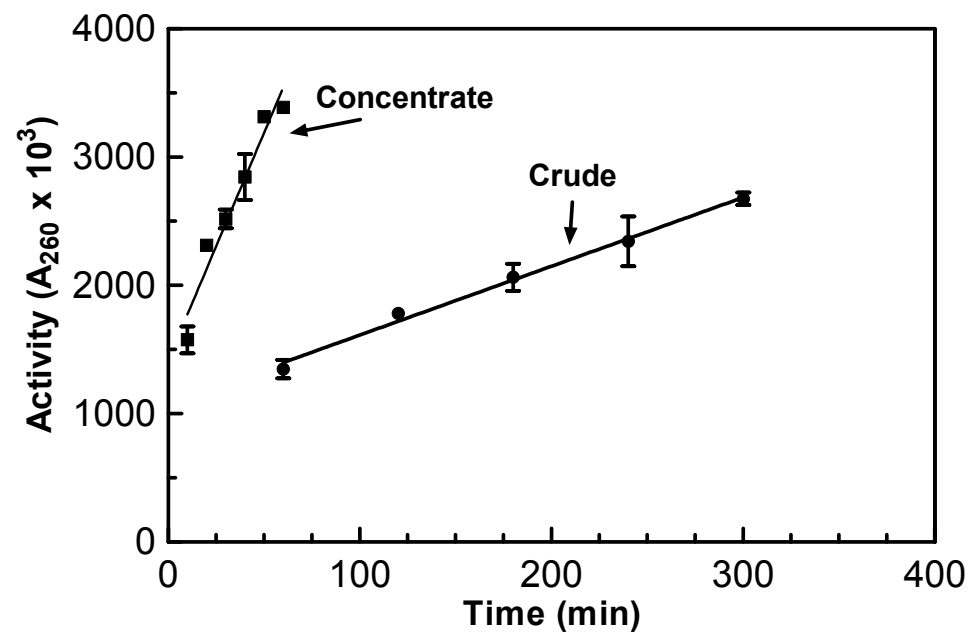

\subsection{Sephadex G-50 Purification}

The next stage of purification involved passing the concentrated sample through a Sephadex G-50 column in refrigerated chamber $\left(2-5{ }^{\circ} \mathrm{C}\right)$. The void volume for the column was determined to be $52.8 \mathrm{~mL}$ using Blue Dextran 2000 (GE Healthcare Cat\# 45-000-048; Hertfordshire, UK). The first fraction demonstrating a measureable absorbance reading at $280 \mathrm{~nm}$ was fraction 9 with additional readings extending to fraction 50. Fractions 9 through 16 had RNase activity (Figure 2). All tubes with RNase activity were pooled. The remaining fractions demonstrated no activity. Purification via Sephadex G-50 resulted in a 91.5-fold increase in specific activity. A typical plot of protein and activity for RNase can be seen in Figure 2.

Figure 2. Typical plots of protein and enzyme activity when $1 \mathrm{~mL}$ of concentrated sample was passed through a Sephadex G-50 column at $2-5^{\circ} \mathrm{C}$. The activity was measured using the acid soluble assay at $55{ }^{\circ} \mathrm{C}$ and protein was estimated by determining the absorbance at $280 \mathrm{~nm}$.

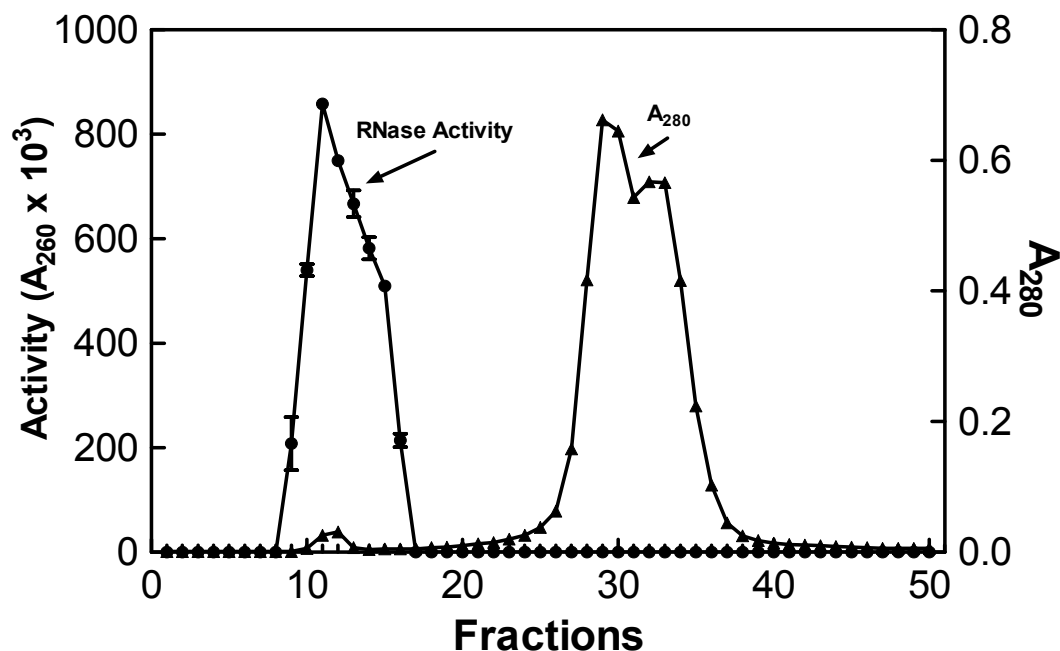




\subsection{Membrane Purification}

Following Sephadex G-50 chromatography, only two protein bands remained, one of which was known to be DNase [5]. The membrane purification system developed by Landry and Levin [6] was then utilized to separate the RNase form the DNase.

Pooled fractions from four Sephadex G-50 refrigerated columns $(211 \mathrm{~mL})$ were concentrated to $45 \mathrm{~mL}$ using the pressurized ultrafiltration cell as described earlier. From this preparation, $10 \mathrm{~mL}$ were purified using 10 DNA coated membranes. This was done for the remaining $35 \mathrm{~mL}$ as well. Following membrane purification, the purified sample was assayed for activity and protein concentration. Membrane purification resulted in the retention of $76 \%$ of the initial activity with a 121 -fold increase in specific activity (Table 1). The overall protein content of the membrane purified RNase was 168 times less than that of the original crude sample, with the final concentration of protein being just under $2 \mathrm{mg}$ (Table 1). Enzyme purity was assessed using 4\%-15\% gradient polyacrylamide gels. The purification of the RNase can be seen in Figure 3.

Figure 3. Enzyme purification was determined using 4\%-15\% gradient polyacrylamide gel electrophoresis. The lanes are as follows: (1) 250-10 kDa protein ladder; (2) crude sample; (3) concentrated sample; (4) Sephadex G-50 sample; and (5) purified RNase.

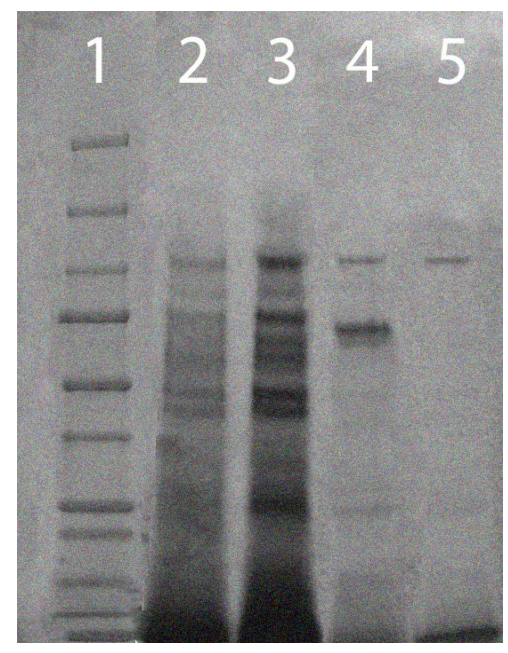

\subsection{Effect of Temperature on the Partially Purified RNase}

The effect of temperature on enzyme activity of the partially purified RNase was assessed two ways. The first method involved using the acid soluble assay after various reaction temperatures. Using this method the optimum and maximum temperatures for enzyme activity was determined to be 70 and $95{ }^{\circ} \mathrm{C}$ respectively, with no detectable activity $95{ }^{\circ} \mathrm{C}$ (Figure 4 ). The activity at the optimum temperature was $73 \%$ greater than at $50{ }^{\circ} \mathrm{C}$.

The second method used a modified version of the real-time spectrophotometric assay developed by Kunitz [7]. $1.0 \mathrm{~mL}$ of partially purified RNase was added to $2.0 \mathrm{~mL}$ of substrate and the decrease in absorbance at $300 \mathrm{~nm}$ was recorded as seen in Figure 5. Prior to analysis both the sample and buffer were equilibrated to the desirable temperature. Using this method the optimum temperature was again found to be $70{ }^{\circ} \mathrm{C}$ however the maximum temperature was not assessed using this method. 
Figure 4. The effect of temperature on the activity of the partially purified RNase. The plots are as follows: (A) plot of all of the temperatures assayed for activity; (B) plot of the temperatures $50-70{ }^{\circ} \mathrm{C}$; and $(\mathbf{C})$ plot of the temperatures $70-95{ }^{\circ} \mathrm{C}$. Activity was measured using the acid soluble assay which was performed in triplicate.
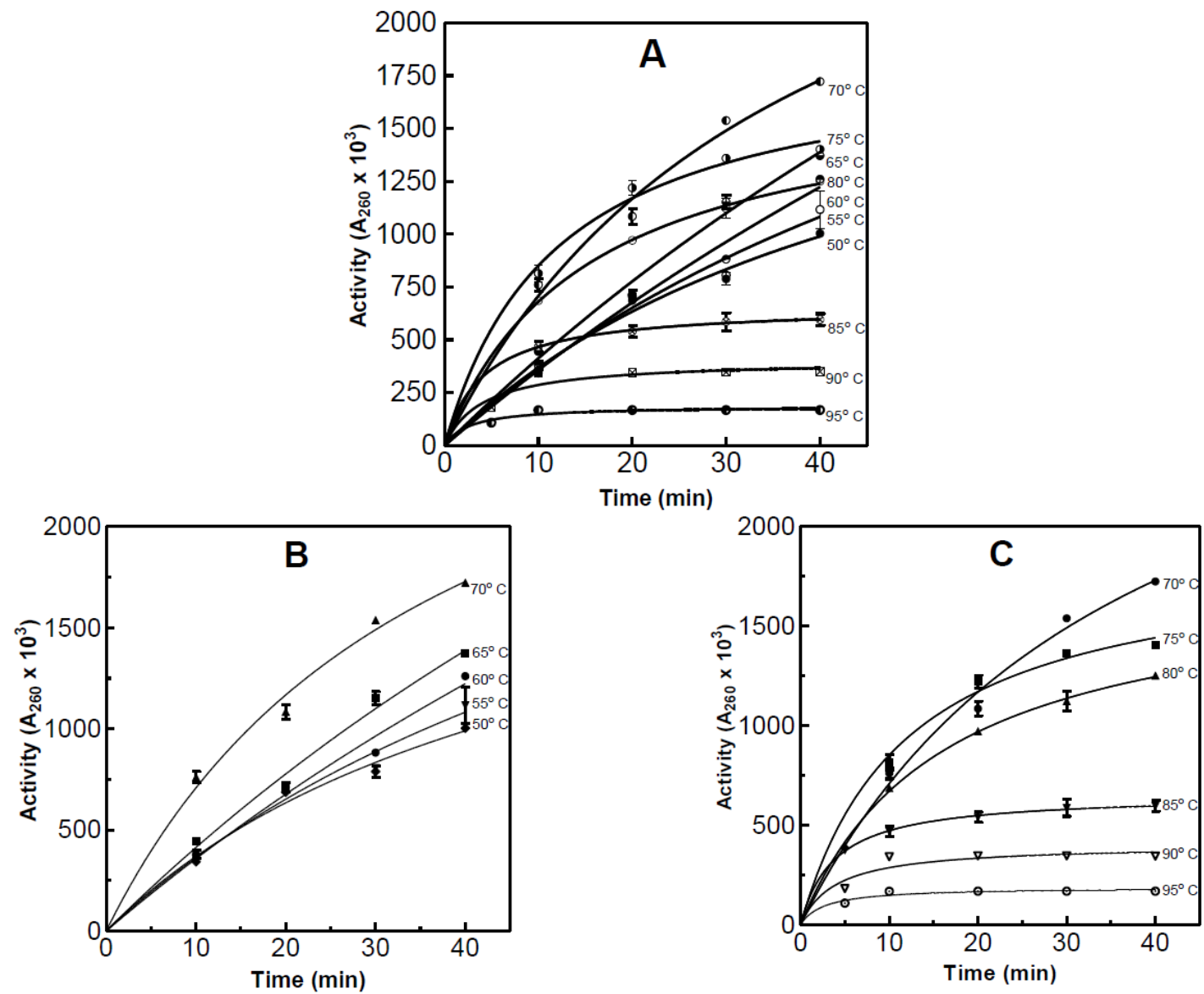

Figure 5. Effect of temperature on partially purified RNase activity. Measurements were in triplicate using a modified version of the real-time assay developed by Kunitz [7].

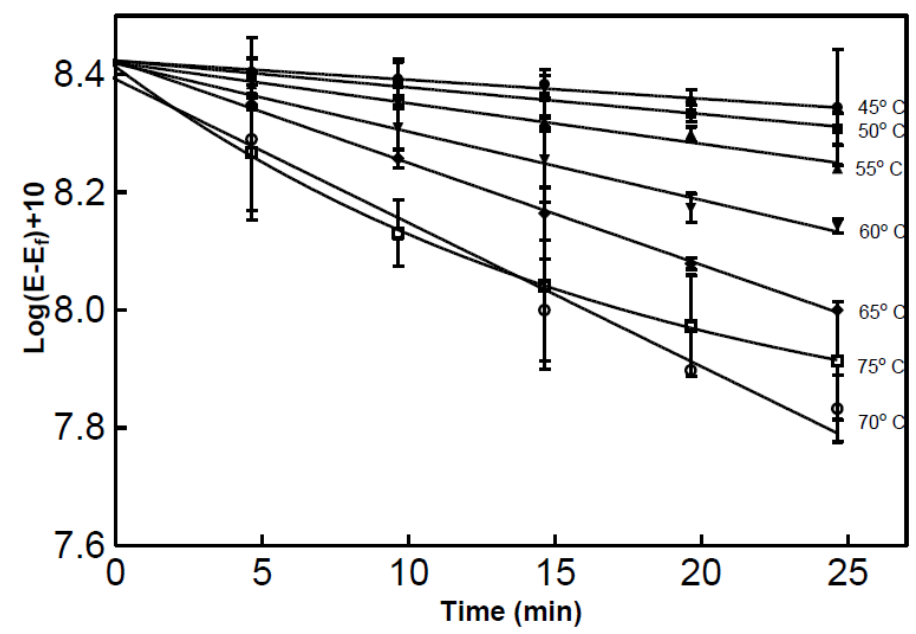

The rate of thermal denaturation was assed at 90 and $95^{\circ} \mathrm{C}$. These two temperatures were selected from the results seen in Figure 4C. The denaturation plot can be seen in Figure 6. An enzyme sample exposed to $90{ }^{\circ} \mathrm{C}$ for $10 \mathrm{~min}$ resulted in a $92 \%$ decrease in activity when compared to the initial 
activity. After $7 \mathrm{~min}$ at $95^{\circ} \mathrm{C}, 100 \%$ of the activity was lost, while enzyme exposed for 6 min to $95{ }^{\circ} \mathrm{C}$ lost $95 \%$ of the activity.

Figure 6. Plots of the denaturation of partially purified RNase at 90 and $95{ }^{\circ} \mathrm{C}$. The assay used for this experiment was a modified version of the acid soluble assay which is explained in detail in the Materials and Methods Section.

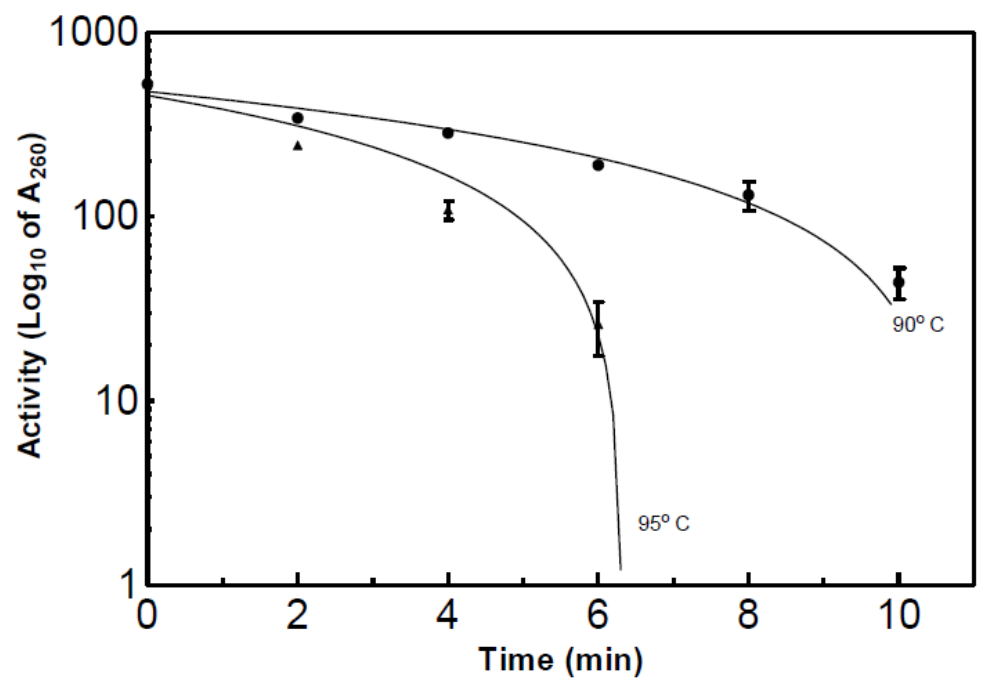

\subsection{Effect of $p H$ on the Partially Purified RNase}

The activity of the partially purified RNase was determined at various $\mathrm{pH}$ values between $\mathrm{pH} 2.0$ and 10.0. A modified version of the acid soluble assay was used which involved adding $0.75 \mathrm{~mL}$ of partially purified RNase to $0.75 \mathrm{~mL}$ of substrate (yeast RNA; $1 \mathrm{mg} / \mathrm{mL}$ (Sigma Cat\# R6625; Milwaukee, WI, USA), $10 \mu \mathrm{mol} \mathrm{MgSO}_{4}$ in a $0.1 \mathrm{M}$ imidazole, malic acid, and glycine buffer, at various $\mathrm{pH}$ ) and allowed to incubate at $55^{\circ} \mathrm{C}$ for $10 \mathrm{~min}$. The rest of the procedure was carried out as described in the Materials and Methods section.

The partially purified RNase demonstrated activity throughout the $\mathrm{pH}$ range of $3.0-9.0$ and exhibited optimum activity at both $\mathrm{pH} 3.0$ and 7.0 (Figure 7). No activity was detected at $\mathrm{pH} 2.0$ or 10.0. The presence of two optimal $\mathrm{pH}$ peaks may indicate the presence of iso- RNases, which is why it is to be considered partially purified.

\subsection{Effect of Dialysis and EDTA on RNase Activity}

Partially purified RNase was dialyzed by filtering the sample with $500 \mathrm{~mL}$ of deionized water via ultrafiltration as described in the Materials and Methods section. Care was taken to ensure that the final sample volume was the same as the initial sample volume prior to dialysis filtration. It was found that there was no significant difference in activity between dialyzed and non-dialyzed sample. The effect of EDTA on enzyme activity was also examined. Partially purified RNase $(0.75 \mathrm{~mL})$ was added to $0.75 \mathrm{~mL}$ of substrate (yeast RNA; $1 \mathrm{mg} / \mathrm{mL}$ (Sigma Cat\# R6625; Milwaukee, WI, USA) in $0.1 \mathrm{M}$ imidazole buffer ( $\mathrm{pH} 7.0$ ) containing $2 \mathrm{mM} \mathrm{MgSO}_{4}$, plus $0 \mathrm{mM}, 0.5 \mathrm{mM}, 1.0 \mathrm{mM}, 1.5 \mathrm{mM}$, or $2.0 \mathrm{mM} \mathrm{Na} \mathrm{maDT}_{2}$ ED) and incubated in a water bath set to $55{ }^{\circ} \mathrm{C}$. The reaction was carried out as previously described. With $2.0 \mathrm{mM}$ of $\mathrm{Na}_{2}$.EDTA present in the substrate, a $35 \%$ decrease in enzyme 
activity was observed. All activity was inhibited when $20 \mathrm{mM}$ of $\mathrm{Na}_{2}$.EDTA was added to the substrate (Figure 8).

Figure 7. Plot of the partially purified RNase $\mathrm{pH}$ profile. The activity was measured using a modified version of the acid soluble assay at $55^{\circ} \mathrm{C}$ with varying $\mathrm{pH}$.

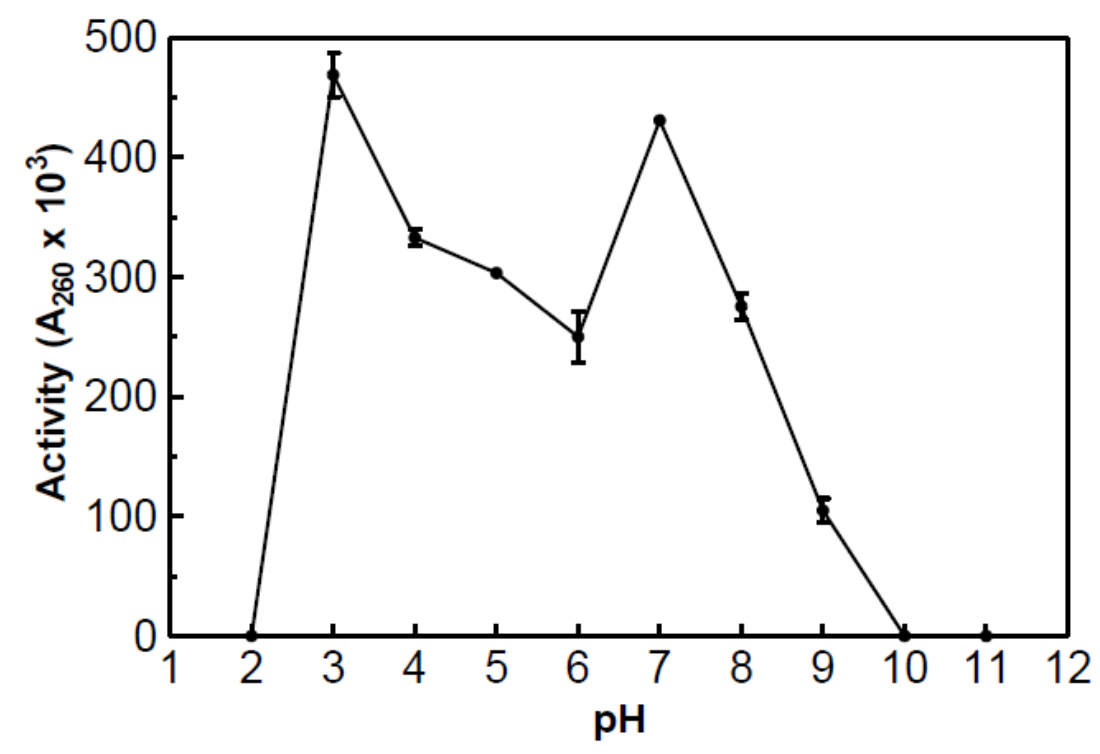

Figure 8. The effect of EDTA on partially purified RNase activity. The results were obtained using the acid soluble assay at $55{ }^{\circ} \mathrm{C}$ with the designated amount of EDTA added to the substrate.

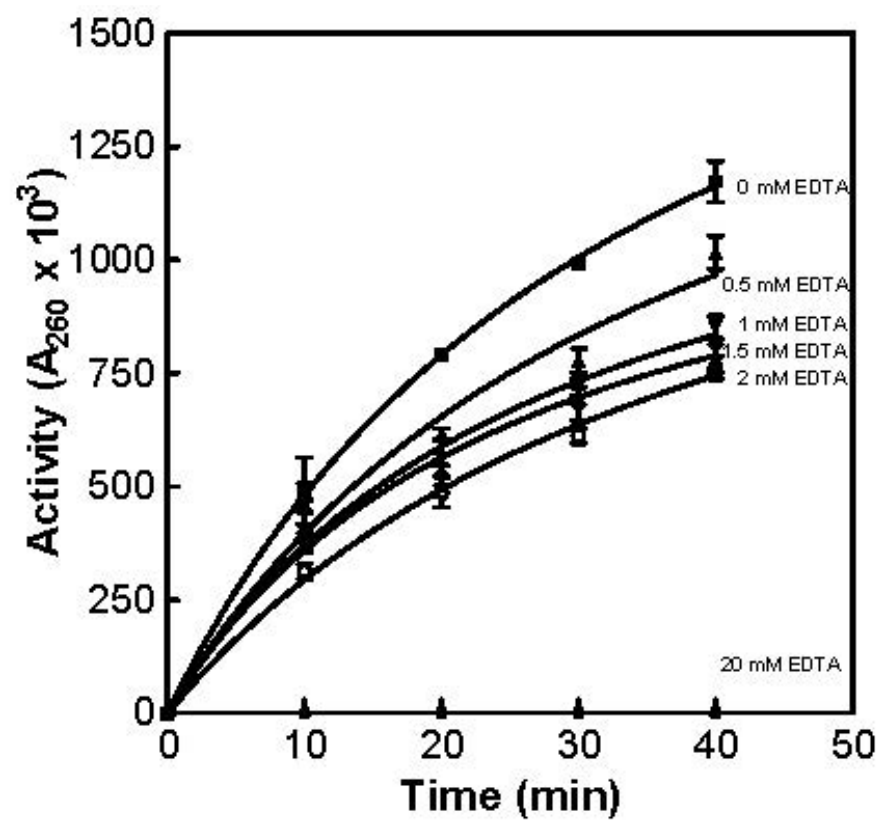

\subsection{Effect of Metal Ions on Enzymatic Activity}

Partially purified RNase stripped of its metal co-factors by the addition of $20 \mathrm{mM} \mathrm{Na}_{2}$ EDTA. This was used to determine the effect of different metal ions on enzyme activity. The ions tested were zinc (as zinc acetate, Fisher Scientific, Cat\# Z20-500; Pittsburgh, PA, USA) magnesium (as magnesium 
sulfate, Fisher Scientific, Cat\# M65-500; Pittsburgh, PA, USA), and manganese (as manganese chloride, Fisher Scientific, Cat\# M87-100; Pittsburgh, PA, USA); the desired metal ion (50 mM) was added to the substrate to ensure that the metal ions would not be sequestered by unbound EDTA. The acid soluble assay at $55^{\circ} \mathrm{C}$ was used to measure the effect of metal ions on enzyme activity (Figure 9). The metal ions zinc and manganese both resulted in the highest amount of activity. The magnesium ion resulted in about $50 \%$ of the activity achieved with the zinc and manganese ions.

Figure 9. The effect of various metal ions on partially purified RNase activity. The results were obtained using the acid soluble assay at $55{ }^{\circ} \mathrm{C}$ with $50 \mathrm{mM} / \mathrm{mL}$ of the designated metal ions added to the substrate. Prior to the experiment $20 \mathrm{mM} / \mathrm{mL}$ of EDTA was added to the partially purified RNase.

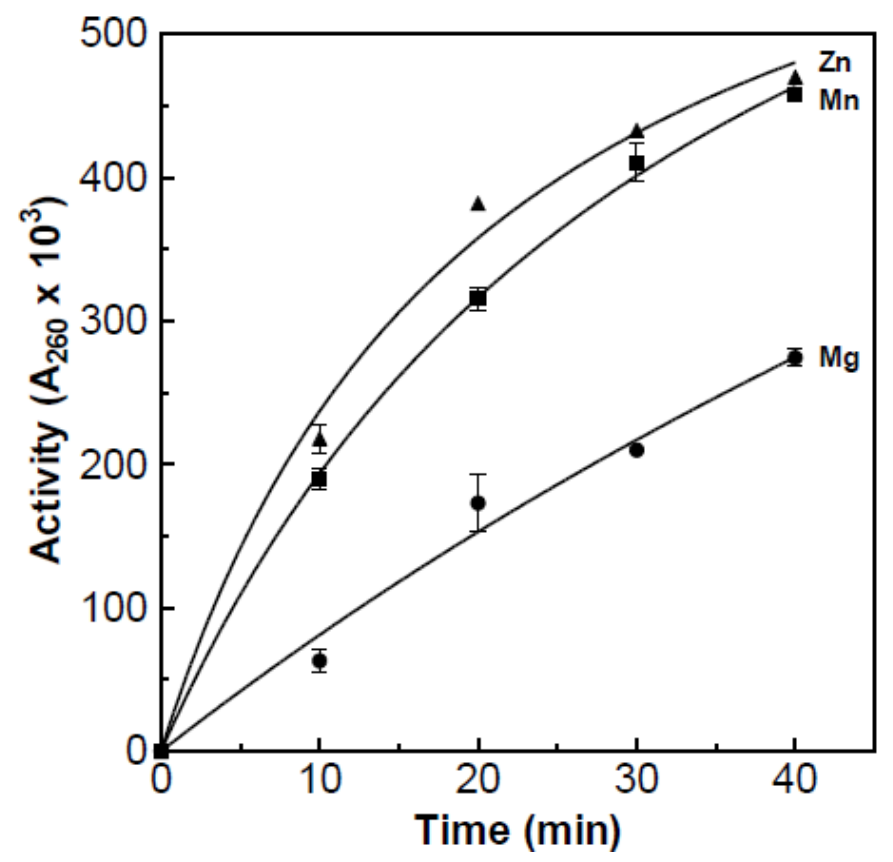

\subsection{Estimated Molecular Weight of the Partially Purified RNase}

The molecular weight of the purified DNase was estimated using a column of Sephadex G-75. The calculated $K_{\mathrm{av}}$ values were plotted against the log molecular weight of the standard proteins. Chromatography of the RNase yielded a log molecular weight of 4.84 and therefore the partially purified RNase has an estimated molecular weight of 69,000 (Figure 10).

\section{9. $\mathrm{K}_{m}$ and $\mathrm{V}_{\max }$ of the Partially Purified RNase}

The $K_{\mathrm{m}}$ and $V_{\max }$ for the partially purified RNase was estimated by plotting the velocities against the substrate concentration (Figure 11). The velocities for each concentration were generated using the acid soluble assay at $55{ }^{\circ} \mathrm{C}$ with varying concentrations of RNA. The RNase was estimated to have a $K_{\mathrm{m}}$ value of 169 and a $V_{\max }$ value of 0.019 . 
Figure 10. Molecular weight determination of the partially purified RNase. Molecular weights of protein standards were: ribonuclease A, 13,700; $\alpha$-chymotypsinogen, 25,000; $\alpha$-amylase, 51,000; and enolase, 82,000. The $\log$ molecular weight of the RNase was determined to be 4.841 , which is roughly equal to a molecular weight of $69 \mathrm{kDa}$.

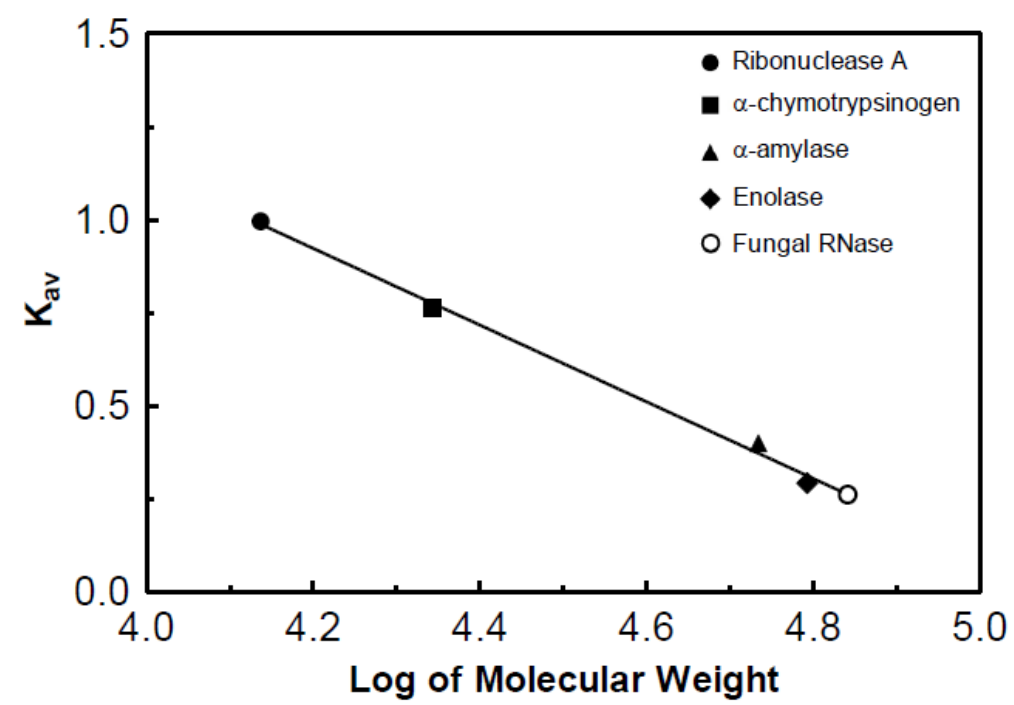

Figure 11. Michaelis-Menten and Lineweaver-Burk plots of RNase activity. The $K_{\mathrm{m}}$ value was estimated to be 169 with a $V_{\max }$ of 0.019 . The acid soluble assay at $55{ }^{\circ} \mathrm{C}$ with varying RNA substrate concentrations was used to determine the velocities. The data was then converted to generate the Lineweaver-Burk plot.

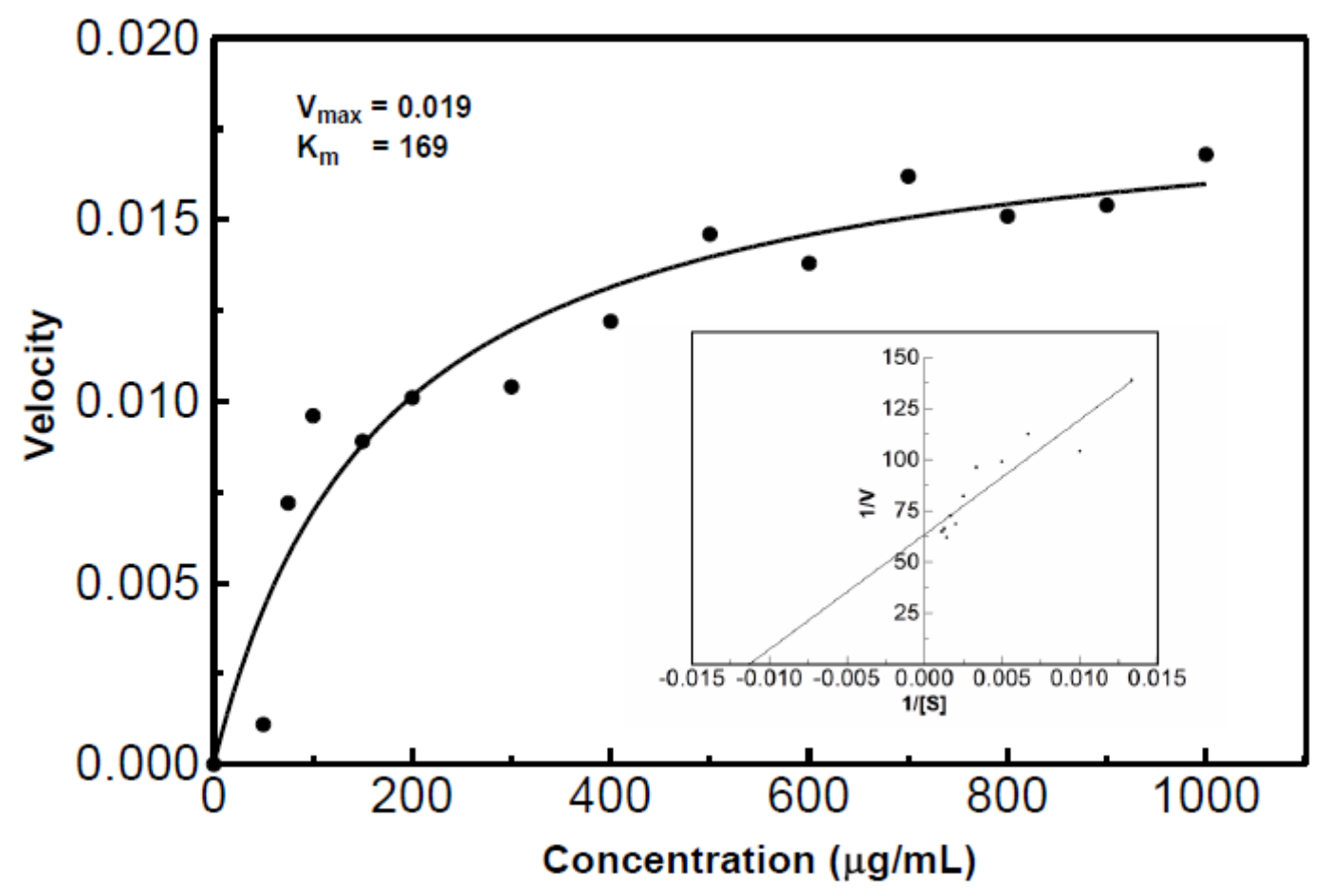




\section{Materials and Methods}

\subsection{Isolation of the Thermophilic Fungus}

The strain (TM-417) used in this manuscript was originally isolated by this laboratory [5].

\subsection{Initial RNase Screening}

TM-417 was inoculated on yeast protein soluble starch media plates (YpSs; 0.4\% yeast extract, $0.1 \% \mathrm{~K}_{2} \mathrm{HPO}_{4}, 0.05 \% \mathrm{MgSO}_{4}, 1.5 \%$ soluble starch, $\mathrm{pH} 7.3$ ) that was modified according to Korn et al. [8] utilizing the dye thionine to detect the presence of an extracellular ribonuclease (RYpSs). RNase activity was indicated by the presence of a pink halo around the isolate.

\subsection{Effect of Temperature on RNase Production}

A correlation between temperature and RNase production was established by inoculating RYpSs agar plates with a $10 \mathrm{~mm}$ plug taken from a stock culture plate. The plates were incubated at various temperatures $\left(2,20,32,37,45,55\right.$, and $\left.60{ }^{\circ} \mathrm{C}\right)$ for five days. The zones of clearing in mm were measured in four different directions from the edge of visible growth to the furthest spot of clearing.

\subsection{Preparation of Sample for RNase Purification}

Isolated cultures were transferred to Fernbach flasks containing $500 \mathrm{~mL}$ of YpSs broth containing 0.2\% yeast RNA (Sigma Cat\# R6625; Milwaukee, WI, USA). Each flask was placed on a rotary shaker set to $115 \mathrm{rpm}$ and incubated at $55{ }^{\circ} \mathrm{C}$. After three days the flasks were allowed to incubate statically for an additional four days. Cell mass was removed from the culture by vacuum filtration through coarse filter paper (Fisher Scientific Filter Paper P8 Cat\# 09-790-12D; Pittsburgh, PA, USA). The filtrate was filtered under vacuum through medium (Fisher Scientific Filter Paper P5 Cat\# S47574D; Pittsburgh, PA, USA), and then through fine filter paper (Fisher Scientific Filter Paper P2 Cat\# S47574D; Pittsburgh, PA, USA). The filtered sample represented the crude enzyme. To inhibit any bacterial and/or fungal growth, $0.02 \%$ sodium azide was added to the crude enzyme sample. All crude enzyme samples were stored at ambient temperature.

\subsection{Sample Purity}

Electrophoresis was carried out in a vertical Bio-Rad Mini-Protean ${ }^{\circledR}$ system using a Tris/Glycine/SDS buffer (Bio-Rad Cat\# 161-0772; Hercules, CA, USA). The sample was diluted 1:1 with a Lamemmli buffer solution containing $950 \mu \mathrm{L}$ Lamemmli buffer and $50 \mu \mathrm{L} \beta$-mercaptoethanol Lamemmli buffer (Bio-Rad Cat\# 161-0737; Hercules, CA, USA)/ $\beta$-mercaptoethanol (Fisher Scientific Cat\# O3446I-100; Pittsburgh, PA, USA). The mixture was heated for $5 \mathrm{~min}$ at $99{ }^{\circ} \mathrm{C}$. Proteins were separated using 4\%-15\% gradient Mini-Protean ${ }^{\circledR}$ TGX ${ }^{\mathrm{TM}} 30 \mu \mathrm{L}$ well precast gels (Bio-Rad Cat\# 456-1083; Hercules, CA, USA). Gels were loaded with $30 \mu \mathrm{L}$ of sample and run at $155 \mathrm{~V}$ for $45 \mathrm{~min}$. Gels were placed on a shaker set to low speed (25 RPM) and stained using $50 \mathrm{~mL}$ of Acqua Stain (Bulldog Bio Co. Cat\# AS001000; Portsmouth, NH, USA) for $60 \mathrm{~min}$. The bands were photographed with a PowerShot G10 Digital Canon Camera (Tokyo, Japan) equipped with an orange 
filter. A 250-10 kDa protein ladder (Dual Color Precision Plus Protein Standards. Bio-Rad Cat\# 1610374; Hercules, CA, USA) used was as a standard.

\subsection{Determination of Protein Content}

Protein was determined by the Lowry method [9] or by measuring absorbance at $280 \mathrm{~nm}$. A blank was generated by substituting the sample with deionized water.

\subsection{Acid Soluble Assay for Enzyme Activity}

RNase activity was determined by measuring acid soluble nucleic acids. The method used in this study was a modified version of the method presented by Eaves and Jeffrie [10]. Enzyme sample $(0.75 \mathrm{~mL}$ ) was added to $0.75 \mathrm{~mL}$ of substrate (yeast RNA, Sigma Cat\# R6625; Milwaukee, WI, USA, $10 \mu \mathrm{mol} \mathrm{MgSO}_{4}$ in $0.1 \mathrm{M}$ imidazole buffer, $\mathrm{pH}$ 7.0) and incubated in a controlled water bath at $25{ }^{\circ} \mathrm{C}$ for $10 \mathrm{~min}$. The reaction was stopped by adding $0.5 \mathrm{~mL}$ of uranylacetate-perchloric acid reagent $(0.25 \%$ uranylacetate in $10 \%$ perchloric acid). Reaction tubes were cooled in an ice bath for $15 \mathrm{~min}$. The mixture was diluted with $2.0 \mathrm{~mL}$ of deionized water and the precipitate removed by centrifugation at 13,400 rpm for $5 \mathrm{~min}$ at ambient temperature. The absorption at $260 \mathrm{~nm}$ was then measured against a reagent blank prepared by adding the uranylacetate-perchloric acid reagent to the substrate prior to the addition of the enzyme. One unit of enzyme activity is defined as an increase in absorbance of 0.1 units in a cuvette of $1 \mathrm{~cm}$ light path at $260 \mathrm{~nm}$.

\subsection{Ultrafiltration Membrane Concentration}

Crude enzyme sample $(250 \mathrm{~mL})$ was dialyzed against deionized water (containing $0.02 \%$ sodium azide) for $12 \mathrm{~h}$ using dialysis tubing (Fisher Scientific Cat\# 21-152-5; Pittsburgh, PA, USA) with a flat width of $40 \mathrm{~mm}$ and a molecular weight cut-off of $6-8 \mathrm{kDa}$.

Prior to sample ultrafiltration, $200 \mathrm{~mL}$ of distilled water followed by $100 \mathrm{~mL}$ of $1 \%(w / v)$ bovine serum albumin (Fisher Biotech, Fraction V, Cat\# BP1605100; Pittsburgh, PA, USA) solution was passed through the pressure cell/membrane apparatus. This was to ensure that no protein from the sample would bind to the membrane. The dialyzed crude enzyme sample was then concentrated using a $500 \mathrm{~mL}$ pressure cell $\left(\right.$ Amicon $^{\odot}$ Cat\# 5124; Billerica, MA, USA) and a $10 \mathrm{kDa}$ cellulose membrane (Millipore $^{\odot}$ Utrafiltration YM10 Dia. $76 \mathrm{~mm}$, Cat\# 13642; Billerica, MA, USA) yielding the concentrated enzyme sample.

\subsection{Sephadex G-50 Column Chromatography}

Sephadex G-50 (MP Biomedicals Cat\# ICN19558010; Solon, OH, USA) was hydrated in deionized water for $3 \mathrm{~h}$ at $100{ }^{\circ} \mathrm{C}$ prior to loading the column. A $45 \mathrm{~cm} \times 2.5 \mathrm{~cm}$ glass column was used. A $34 \mathrm{~cm}$ long column of Sephadex G-50 was equilibrated for $24 \mathrm{~h}$ with $0.5 \mathrm{M}$ imidazole buffer (pH 7.0) containing $0.02 \%$ sodium azide. A portion $(1.0 \mathrm{~mL})$ of concentrated sample was loaded onto the bottom of the gel bed and eluted ascendingly with the $0.5 \mathrm{M}$ imidazole buffer at a rate of $2 \mathrm{~mL} / \mathrm{min}$ in a refrigerated chromatography cabinet $\left(2-5{ }^{\circ} \mathrm{C}\right)$. Fractions $(6.6 \mathrm{~mL})$ were collected using a Gilson FC 203B fraction collector (Middleton, WI, USA). All fractions which demonstrated RNase activity were 
pooled together. Activity was measured using the acid soluble assay at $55^{\circ} \mathrm{C}$ with an incubation time of $20 \mathrm{~min}$.

\subsection{Membrane Preparation for Affinity Purification}

A 47 mm, $0.2 \mu \mathrm{m}$ FP-Vericel membrane (Pall Life Sciences Cat\# 66477; Radnor, PA, USA) was inserted into a Millipore ${ }^{\odot}$ membrane filtration unit and rinsed under vacuum with $200 \mathrm{~mL}$ of deionized water. One gram of salmon sperm DNA (USB Cat\# 14405100 GM; Santa Clara, CA, USA) was dissolved in $50 \mathrm{~mL}$ of $2 \times \mathrm{SSC}$ buffer $(1.75 \%$ sodium chloride, $0.88 \%$ sodium citrate, adjusted to $\mathrm{pH}$ 7.0) and boiled for one minute. The boiled solution was placed in ice and cooled to $10{ }^{\circ} \mathrm{C}$. The rinsed membrane was added to the solution and placed in an iced bucket. The iced bucket was placed on a shaker at 75 RPM. After 60 min the membrane was removed, rinsed with deionized water and dried using a stream of hot air.

\subsection{Affinity Membrane DNase Separation}

$10 \mathrm{~mL}$ of sample from four concentrated Sephadex G-50 column runs (45 $\mathrm{mL}$ total volume) was chilled to $5{ }^{\circ} \mathrm{C}$ in a $200 \mathrm{~mL}$ beaker and place in an iced bucket on a shaker set to $50 \mathrm{rpm}$ in a $2{ }^{\circ} \mathrm{C}$ refrigerator. DNA coated membranes were prepared according to Landry and Levin [6] and added to the chilled sample and removed after $3 \mathrm{~min}$ and then removed. The remaining $35 \mathrm{~mL}$ of concentrated Sephadex G-50 sample was purified in the same manner. All membranes were discarded after one use.

\subsection{Spectrophotometric Assay of RNase Activity}

The method used for this study was a modified version of the one used by Kunitz [7]. Approximately $2.25 \mathrm{~mL}$ of substrate (yeast RNA; $1 \mathrm{mg} / \mathrm{mL}$ (Sigma Cat\# R6625; Milwaukee, WI, USA), $10 \mu \mathrm{mol} \mathrm{MgSO}_{4}$ in $0.1 \mathrm{M}$ imidazole, $\mathrm{pH}$ 7.0) was added to a cuvette $(1 \mathrm{~cm}$ path length) and placed into a temperature controlled cuvette holder and equilibrated to the desired temperature. Partially purified enzyme $(0.75 \mathrm{~mL})$ was added and mixed with a cuvette mixing device, for a total volume of $3 \mathrm{~mL}$. The decrease in absorbance at $300 \mathrm{~nm}$ was recorded. The blank consisted of $2.25 \mathrm{~mL}$ of substrate solution and $0.75 \mathrm{~mL}$ of deionized water. The recorded absorbance was then converted to $\log \left(E-E_{f}\right)+10$ where $E=A_{300}$ and $E_{f}=A_{300}$ after 30 min of digestion.

\subsection{Enzyme Destruction Assay}

Two water baths were used for this assay, one set to $55^{\circ} \mathrm{C}$ and another set to 90 and $95{ }^{\circ} \mathrm{C}$. The enzyme sample was placed in the water bath set to the desired temperature and allowed to equilibrate. Once the enzyme preparation reached the desired temperature, the enzyme $(0.75 \mathrm{~mL})$ was removed and added to $0.75 \mathrm{~mL}$ of substrate (yeast RNA; $1 \mathrm{mg} / \mathrm{mL}$ (Sigma Cat\# R6625; Milwaukee, WI, USA), $10 \mu \mathrm{mol} \mathrm{MgSO}_{4}$ in $0.1 \mathrm{M}$ imidazole, $\mathrm{pH} 7.0$ ) equilibrated at $55{ }^{\circ} \mathrm{C}$. The incubation time was $10 \mathrm{~min}$. The enzyme sample was tested at various time intervals during the incubation at the desired temperature. 


\subsection{Molecular Weight Determination via Sephadex G-75 Chromatography}

The molecular weight was determined using a column of Sephadex G-75 (Pfaltz \& Bauer Inc. Cat\# 50-145-149; Waterbury, CT, USA) with a gel bed of $2.5 \times 30 \mathrm{~cm}$ and a pH 7, $0.5 \mathrm{M}$ imidazole buffer containing $0.02 \%$ sodium azide. The flow rate for the column was $0.8 \mathrm{~mL} / \mathrm{min}(48 \mathrm{~mL} / \mathrm{h})$. The $K_{\mathrm{av}}$ values of enzymes with known molecular weights were used to determine the molecular weight from a standard curve. Highly purified ribonuclease A (13,700 Da; MP Biomedicals Cat\# ICN19398050; Solon, OH, USA), $\alpha$-chymotrypsinogen (25,000 Da; Crescent Chemical Co. Cat\# 50-247-444; Islandia, NY, USA), $\alpha$-amylase (51,000 Da; Fisher Scientific Cat\# S25135; Pittsburgh, PA, USA), and enolase (82,000 Da; MP Biomedicals Cat\# ICN1934989; Solon, OH, USA) as well as Blue Dextran 2000 (GE Healthcare Cat\# 45-000-048; Hertfordshire, UK) were used to generate the standard curve.

\section{Conclusions}

In sum, a thermophilic RNase was partially purified and characterized in terms of its optimal conditions, molecular weight, and certain kinetic properties. One of the most interesting findings regarding this nuclease is its activity profile at near boiling conditions. This observation is not surprising since the maximum temperatures from thermophilic organisms should theoretically be higher than other mesophiilic enzymes.

It should be noted that some RNases from the fungi kingdom have been shown to exhibit angiogenic, antitumor, and immunosuppressive activities [11-13]. These findings have increased the interest in fungal RNase purification and characterization. Yet, there has been very little, if any research done regarding nucleases from thermophilic fungi. RNases with potential medical benefits are largely from edible mushrooms belonging to the phyla basidiomycota [13]. The presented RNase was isolated from a thermophilic Chaetomium sp. [5]. Filamentous ascomycetes may produce extracellular nucleases that may be as promising, if not better than currently studied fungi.

\section{Conflicts of Interest}

The authors declare no conflict of interest.

\section{References}

1. Mishra, N.C. Nucleases: Molecular Biology and Applications; John Wiley \& Son: Hoboken, NJ, USA, 2002.

2. Kunitz, M. Crystalline ribonuclease. J. Gen. Physiol. 1940, 24, 15-32.

3. Mishra, N.C. Molecular Biology of Nucleases; CRC Press: Boca Raton, FL, USA, 1995.

4. Raines, R.T. Ribonuclease A. Chem. Rev. 1998, 98, 1045-1066.

5. Landry, K.S.; Vu, A.; Levin, R.E. Purification of an inducable DNase from a thermophilic fungus. Int. J. Mol. Sci. submitted for publication.

6. Landry, K.S.; Levin, R.E. Development of a novel affinity membrane purification system for deoxyribonuclease. Appl. Biochem. Biotechnol. 2013, doi:10.1007/s12010-013-0654-8. 
7. Kunitz, M. A spectrophotometric method for the measurement of ribonuclease activity. J. Biol. Chem. 1946, 164, 563-568.

8. Korn, K.; Greiner-Stoffele, T.; Hahn, U. Ribonuclease assays utilizing toluidine blue indicator plates, methylene blue, or fluorescence correlation spectroscopy. Methods Enzymol. 2001, 341, $142-153$.

9. Lowry, O.H.; Rosebrough, N.J.; Farr, A.L.; Randall, R.J. Protein measurement with the Folin phenol reagent. J. Biol. Chem. 1951, 193, 265-275.

10. Eaves, G.N.; Jeffries, C.D. Isolation and properties of an exocellular nuclease of serratia marcescens. J. Bacteriol. 1963, 85, 273-278.

11. Schein, C.H. From housekeeper to microsurgeon: The diagnostic and therapeutic potential of ribonucleases. Nat. Biotechnol. 1997, 15, 529-536.

12. D'Alessio, G. New and cryptic biological messages from RNases. Trends Cell Biol. 1993, 3, 106-109.

13. Fang, E.F.; Ng, T.B. Ribonucleases of different origins with a wide spectrum of medicinal applications. Biochim. Biophys. Acta 2011, 1815, 65-74.

(C) 2014 by the authors; licensee MDPI, Basel, Switzerland. This article is an open access article distributed under the terms and conditions of the Creative Commons Attribution license (http://creativecommons.org/licenses/by/3.0/). 